\title{
Risk of Salmonella in Various Poultry Farming and Processing Operations around Mumbai, India
}

\author{
Rupesh Waghamare ${ }^{1 *}$, Ashish Paturkar ${ }^{2}$, Vilas Vaidya $^{2}$, Ravindra Zende $^{2}$, \\ Milind Chavak ${ }^{3}$ and Santosh Moregaonkar ${ }^{1}$
}

\author{
${ }^{1}$ College of Veterinary and Animal Sciences Parbhani Maharashtra, India \\ ${ }^{2}$ Department of Veterinary Public Health, Mumbai Veterinary College, Parel, Mumbai \\ Maharashtra, India Maharashtra, India \\ ${ }^{3}$ Poultry Diagnostic and Research Centre Venkateshwara Hatcheries Pvt. Ltd Pune, \\ Maharashtra, India
}

*Corresponding author

\begin{tabular}{|c|}
\hline Keywords \\
\hline $\begin{array}{l}\text { Salmonella } \\
\text { serotypes, Poultry } \\
\text { farms, Litter, } \\
\text { Poultry processing } \\
\text { stages, Evisceration }\end{array}$ \\
\hline Article Info \\
\hline $\begin{array}{l}\text { Accepted: } \\
\text { 10 July } 2020 \\
\text { Available Online: } \\
10 \text { August } 2020\end{array}$ \\
\hline
\end{tabular}

\section{A B S T R A C T}

\begin{abstract}
Shift in the process of traditional poultry supply chain to vertical integration has developed way for poultry meat availability in India, but there is food-borne risk for human health by contamination with Salmonella spp. Therefore, the present research work was planned to study risk of Salmonella spp. in chicken meat production. Samples $(n=684)$ were collected from farms (non-integrated and integrated) and processing units (semi-automated and automated) located around Mumbai, India and subjected to Salmonella spp. detection. Isolation of Salmonella spp. was carried out following IS 5887. The obtained isolates were subjected to identification biochemical tests, PCR testing for specific Salmonella spp. gene (invA) and serological identification. The results indicate that, over all occurrences of Salmonella spp. in farming and processing system were $6.70 \%$ and $7.53 \%$, respectively. Higher isolation rate was observed $(\mathrm{p}<0.05)$ amongst various farms and processing units. Positive sample frequencies of Salmonella spp. found higher in litter $(20.83 \%)$, faeces $(10.41 \%)$, de-feathering $(16.66 \%)$ and evisceration $(25.00 \%)$. Amongst environmental samples of processing unit, knife $(16.66 \%)$ and evisceration workers hands $(12.50 \%)$ found to be major cross contaminating risk points. The results highlighted relevance of farm and processing level contamination for Salmonella spp. Therefore, it is essential to apply multiple interventions like, sourcing of Salmonella free chicks, litter management at farm, HACCP plan at the processing stages, use of chlorine wash and systematic cleaning or sanitation programs to avoid cross contamination.
\end{abstract}

\section{Introduction}

Microbiological risk factors are so prevailing that they can be found in almost all systems of poultry production (Yang et al., 2014), if products are improperly treated while handling, cooking or post cooking and storage. Salmonella has been pathogen of significance, and is a major cause of gastroenteritis in humans (Mead et al., 1999). 
Salmonella illness has linked with exposure to meat, a review of the Centers for Disease Control and Prevention (CDC) outbreak data from 2006 to 2011 indicated that 10 out of 25 outbreaks were related to live poultry, shell eggs, or further processed poultry products. Nine percent of United States (US) travellers with Salmonellosis were reported to acquire Salmonella infection while travelling from India (Jennifer and Watkins, 2017).

India is the world's second largest emerging economy with large and rapidly expanding poultry sector at annual growth rate of 10-12 percent for broiler production (Kotaiah, 2016). The consumer demand for processed poultry products like chilled or frozen chicken has also been increased. Indian broiler production for year 2016 estimated to be 4.2 million tons. with $3.1 \mathrm{~kg}$ per capita consumption of poultry meat per year (USDA-GAIN, 2015). Shift in the process of traditional poultry supply chain to vertical integration has developed way for poultry meat availability and better value creation of poultry meat products. Still there is foodborne risk for human health which includes microbiological risks wherein, Salmonella spp. contamination is important risk (Kiilholma, 2007).

The problem of Salmonella in Indian poultry is exacerbated by modern conditions of intensive rearing, where large numbers of birds are kept together and high-rate processing; in which carcasses remain in close proximity throughout the operation which favours the spread of any pathogens that may gain access to the flock. It is often not possible to trace back Salmonella contamination to the original source because risk assessment on Salmonella in meat with information on food handling and processing practices is rarely available (EC, 2008). Risk assessment made by Food and Agriculture Organization (FAO) indicates that reduction of Salmonella prevalence in poultry flocks helps to reduce the occurrence of Salmonellosis in humans. Microbial risk assessment of poultry for Salmonella has been considered as an essential basis for the management of foodborne hazards which results in reduction of human health risk (WHO/FAO, 2002 and FAO, 2016).

Research work carried out by various workers in India reported prevalence of Salmonella either in few variables of farms or retail shop final products final products (Bhuvaneswari et al., 2015 and Waghamare et al., 2017), but there is no complete strategic study on assessment of Salmonella in poultry farm and processing environment. The present study was planned for identifying risk of occurrence of Salmonella spp., in chicken meat production chain with different farming and processing systems.

\section{Materials and Methods}

\section{Sampling sites}

The commercial broiler farms 24 each managed under non-integrated and integrated systems with capacity of $1500-2000$ birds per farm, birds aged between 35 to 42 days supplies birds to two different chicken processing units named semi-automated and automated processing plant, respectively situated around Mumbai city, Maharahstra, India were selected under study.

\section{Sample collection}

A total of 684 samples were collected in period of December 2015 to December 2017. Farm level samples $(n=432)$ samples comprising of 216 each from non-integrated $(\mathrm{n}-12)$ and integrated $(\mathrm{n}=12)$ commercial broiler farms were collected. From these two farm types 48 samples of each source were collected which, comprises of water, feed, 
faeces, litter and various swabs (cloaca, drinker, feeder, workers hand and walls). A total of 252 samples from semi-automated and automated processing unit comprising of a chicken processing stage wise swab samples (post bleeding, scalding, de-feathering, evisceration and chlorination) and environmental samples (water, ice, scalding water and swabs of utensil, defeaters, carcass contact surfaces, workers hand and packaging material) were collected. From both the processing unit a six replicates at every source from various processing stages and environment were collected except workers hands (twelve replicates) at evisceration and deboning stage. Neck sample of post eviscerated and chlorinated carcass were also collected. Swabbing was done using transportable sterile swab (Hi-Media) applied with firm rolling pressure. The swabs were placed immediately in a sterile container with Cairy Blair transport medium whereas, other samples were collected in sterile poly bags. All the samples after collection brought to the laboratory under chilled conditions.

\section{Isolation and Confirmation of Salmonella spp.}

Isolation of Salmonella spp. from various samples collected was carried out by pre enrichment with buffered peptone water, enrichment in Rapport Vassiliadis broth (Himedia) followed by selective plating on XLD and BGSA (Himedia), according to IS 5887 (Part 3): 1999 (Reaffirmed in 2005). Presumptive Salmonella colonies were streaked onto nutrient agar slants (Himedia.) and refrigerated $\left(4^{\circ} \mathrm{C}\right)$ after incubation. Colonies showing typical Gram negative, non spore forming short rod shaped appearance were further subjected to biochemical characterization with biochemically negative for hydrolysis of urea, positive for TSI with alkaline slant (red), acid butt (yellow) with $\mathrm{H}_{2} \mathrm{~S}$ gas production and positive citrate utilization considered as positive for Salmonella spp. Biochemically confirmed isolates were further characterized by PCR assay for invA gene as per protocol of Rahn et al., (1992). Randomly selected PCR positive isolates were submitted to Poultry Diagnostics and Research Centre, Lonikalbhor, Pune for serotyping according to the Kauffmann-White scheme.

\section{Statistical analysis}

Results obtained were subjected for ANOVA and Paired t test analysis using WASP (ICAR, India) software.

\section{Results and Discussion}

The different rate of isolation of Salmonella from broiler poultry farms and processing units are shown in Table 01 and Table 02. The results indicate that, over all occurrences of Salmonella spp. in farming and processing system were 6.70 and 7.53 per cent, respectively. The occurrence of Salmonella in non-integrated and completely integrated farming system was 12.03 and 1.38 , per cent respectively. Significant difference $(p<0.05)$ was observed within the farming systems. Amongst the various samples higher Salmonella occurrence rate was observed in litter $(20.83 \%)$ and faeces $(10.41 \%)$ followed by cloacal swabs $(8.33 \%)$, water $(8.33 \%)$ and drinker $(6.28 \%)$.

As per the results depicted in Table No 02 occurrence Salmonella spp. for semiautomated and automated processing unit ( $\mathrm{p}$ $<0.05)$ was 11.11 and 3.9, percent respectively. Considering the various stages of processing defeathering $(16.66 \%)$ and evisceration $(25 \%)$ were found to be critical stages of contamination. Environmental samples differ non significantly between the semi-automated and automated processing unit. 
Table.1 Occurrence of Salmonella spp. in samples analyzed from various poultry farming systems

\begin{tabular}{|c|c|c|c|c|c|c|c|c|c|c|c|c|}
\hline \multirow{3}{*}{ Sr. no. } & \multirow{3}{*}{$\begin{array}{l}\text { Farming } \\
\text { system }\end{array}$} & \multirow{3}{*}{$\begin{array}{c}\text { Total } \\
\text { number of } \\
\text { samples } \\
\text { from } \\
\text { various } \\
\text { sources }\end{array}$} & \multicolumn{9}{|c|}{ Various sources of contamination ( $n=48$ each source/systems) } & \multirow{3}{*}{$\begin{array}{c}\text { Total number } \\
\text { of positive } \\
\text { samples with } \\
\text { per cent } \\
\text { occurrence }\end{array}$} \\
\hline & & & $\begin{array}{c}\text { Cloacal } \\
\text { Swab }\end{array}$ & Feeder & Drinker & Wall dust & $\begin{array}{c}\text { Worker } \\
\text { Hand }\end{array}$ & Feed & Litter & Feces & $\begin{array}{l}\text { Drinking } \\
\text { water }\end{array}$ & \\
\hline & & & \multicolumn{9}{|c|}{ Number of positive samples } & \\
\hline 1 & $\begin{array}{c}\text { Non } \\
\text { integrated }\end{array}$ & 216 & 4 & $\mathbf{0}$ & 3 & 1 & 1 & $\mathbf{0}$ & 9 & 4 & 4 & $26^{a}(12.03)$ \\
\hline 2 & Integrated & 216 & $\mathbf{0}$ & $\mathbf{0}$ & 0 & 1 & $\mathbf{0}$ & $\mathbf{0}$ & 1 & 1 & $\mathbf{0}$ & $3^{b}(1.38)$ \\
\hline & otal & 432 & $\begin{array}{c}4 \\
{[8.33]}\end{array}$ & 0 & $\begin{array}{c}3 \\
{[6.25]}\end{array}$ & $\begin{array}{c}2 \\
{[4.16]}\end{array}$ & $\begin{array}{c}1 \\
{[2.08]}\end{array}$ & $\mathbf{0}$ & $\begin{array}{c}10 \\
{[20.83]}\end{array}$ & $\begin{array}{c}5 \\
{[10.41]}\end{array}$ & $\begin{array}{c}4 \\
{[8.33]}\end{array}$ & 29 [6.7] \\
\hline
\end{tabular}

Values in the same column with the different superscripts letters are significantly different at 1 and $5 \%$ level of significance 
Table.2 Occurrence of Salmonella spp. in samples analyzed from poultry processing units

\begin{tabular}{|c|c|c|c|c|}
\hline \multirow{2}{*}{$\begin{array}{l}\text { Sr. } \\
\text { No }\end{array}$} & \multirow[t]{2}{*}{ Sample source } & \multicolumn{2}{|c|}{ Poultry processing unit } & \multirow{2}{*}{$\begin{array}{l}\text { No of isolates (\% } \\
\text { occurrence) }\end{array}$} \\
\hline & & $\begin{array}{c}\text { Semi- } \\
\text { automated }\end{array}$ & Automated & \\
\hline \multicolumn{2}{|c|}{$\begin{array}{l}\text { A) Processing stages ( } n=6 \text { per stage } \\
\text { /unit) }\end{array}$} & $\mathrm{n}=\mathbf{4 2}$ & $\mathrm{n}=42$ & $n=84$ \\
\hline 1 & Post bleeding & 00 & 00 & $\mathbf{0}$ \\
\hline 2 & Post scalding & 00 & 00 & $\mathbf{0}$ \\
\hline 3 & Post defeathering & 02 & 00 & $2(16.66)$ \\
\hline 4 & Post evisceration & 02 & 01 & $3(25.00)$ \\
\hline 5 & $\begin{array}{l}\text { Neck sample of post eviscerated } \\
\text { carcass }\end{array}$ & 02 & 01 & $3(25.00)$ \\
\hline 6 & Post chlorination & 01 & 00 & $1(8.33)$ \\
\hline 7 & $\begin{array}{l}\text { Neck sample of post chlorinated } \\
\text { carcass }\end{array}$ & 01 & 00 & $1(\mathbf{8 . 3 3})$ \\
\hline \multicolumn{2}{|c|}{$\begin{array}{c}\text { Number of Positive isolates (percent } \\
\text { occurrence) }\end{array}$} & $08(19.04)$ & 02 (4.76) & $10(11.90)$ \\
\hline \multicolumn{5}{|c|}{ t test : Significant difference at $5 \%$ level for processing stages } \\
\hline \multicolumn{2}{|c|}{$\begin{array}{l}\text { B) Environmental samples }(n=6 \text { per } \\
\text { source /unit except \# where } n=12)\end{array}$} & $\mathrm{n}=\mathbf{8 4}$ & $\mathrm{n}=84$ & $n=168$ \\
\hline 8 & Washing water & 00 & 00 & $\mathbf{0}$ \\
\hline 9 & Scalding water & 00 & 00 & $\mathbf{0}$ \\
\hline 10 & Defeathering machine & 01 & 00 & $\mathbf{1}(\mathbf{8 . 3 3})$ \\
\hline 11 & $\begin{array}{l}\text { Worker hands\# } \\
\text { (Evisceration) }\end{array}$ & 01 & 02 & $3(12.50)$ \\
\hline 12 & Carcass contact platform & 01 & 00 & $\mathbf{1}(\mathbf{8 . 3 3})$ \\
\hline 13 & Chopping board & 01 & 00 & $\mathbf{1}(\mathbf{8 . 3 3})$ \\
\hline 14 & Knife swab & 02 & 00 & 2 (16.66) \\
\hline 15 & Deboning table & 00 & 00 & $\mathbf{0}$ \\
\hline 16 & Worker hand (Deboning)\# & 00 & 00 & $\mathbf{0}$ \\
\hline 17 & Deboning cone & 00 & 01 & $1(8.33)$ \\
\hline 18 & Ice & 00 & 00 & 0 \\
\hline 19 & Cloacal swab & 00 & 00 & $\mathbf{0}$ \\
\hline \multicolumn{2}{|c|}{$\begin{array}{r}\text { Number of Positive isolates (percent } \\
\text { occurrence) }\end{array}$} & $06(7.14)$ & $03(3.57)$ & $9(5.35)$ \\
\hline & $\begin{array}{r}\text { Total Number of Positive isolates } \\
\text { (percent occurrence) }\end{array}$ & $14(11.11)$ & $5(3.9)$ & $19(7.53)$ \\
\hline
\end{tabular}


Table.3 Serotypes of Salmonella spp. isolated from poultry farms and processing units

\begin{tabular}{|c|c|c|c|}
\hline Sr. No. & Sample Code & Source & Serotype \\
\hline \multicolumn{4}{|c|}{ A) Poultry Farms } \\
\hline \multicolumn{4}{|c|}{ I) Non-integrated } \\
\hline 1 & NICS 9 & Cloacal swab & S. Virchow \\
\hline 2 & NICS8 & Cloacal swab & Non-Typable \\
\hline 3 & NIDW 7 & Drinking water & Non Typable \\
\hline 4 & NIFL1 & Litter & S. Newport \\
\hline 5 & NIFL9 & Litter & S. Virchow \\
\hline 6 & NIFL 7 & Litter & Non Typable \\
\hline 7 & NIF8 & Faeces & S. Virchow \\
\hline 8 & NIDR 7 & Drinker & S. Virchow \\
\hline 9 & NIDR6 & Drinker & $S$. Typhimurium \\
\hline 10 & NIWH6 & Worker hand & $S$. Typhimurium \\
\hline 11 & PIL1 & Litter & S. Virchow \\
\hline 12 & PIL3 & Litter & Non Typable \\
\hline 13 & PIF7 & Faeces & S. Virchow \\
\hline 14 & PIF3 & Faeces & Non Typable \\
\hline 15 & PIDW5 & Drinking water & S. Typhimurium \\
\hline \multicolumn{4}{|c|}{ III) Integration } \\
\hline 16 & VVAL & Litter & Non Typable \\
\hline \multicolumn{4}{|c|}{ B) Poultry Processing units } \\
\hline \multicolumn{4}{|c|}{ I) Semi-automated } \\
\hline 17 & SCDM4 & Defeathering machine & S. Newport \\
\hline 18 & SCWH4 & Worker hand (evisceration) & S. Virchow \\
\hline 19 & SCCP4 & Carcass contact platform & Non Typable \\
\hline 20 & SCCB5 & Chopping board & $S$. Typhimurium \\
\hline 21 & SCKS4 & Knife swap & S. Virchow \\
\hline 22 & SCPD2 & Post defeathering & S. Virchow \\
\hline 23 & SCPE 4 & Post evisceration & S. Virchow \\
\hline 24 & SCCLWash4 & Post washing / chlorination & Non Typable \\
\hline 25 & SCNC4 & Neck skin of eviscerated bird carcass & S. Virchow \\
\hline \multicolumn{4}{|c|}{ II) Automated } \\
\hline 26 & ACWH6 & Worker hand (evisceration) & $S$. Typhimurium \\
\hline 27 & ACDC6 & Deboning cone & $S$. Newport \\
\hline 28 & ACPE3 & Post evisceration & Non Typable \\
\hline
\end{tabular}

Higher occurrence rate of Salmonella spp. was observed in knife swabs $(16.66 \%)$ and evisceration workers hand $(12.50 \%)$, followed by defeathring machine, carcass contact platform chopping board and deboning cone $(8.33 \%)$.
Table 03 shows the source wise serotypes of Salmonella, out of total 48 isolates randomly selected 28 isolates were subjected for serotyping these isolates showed three distinct serotypes namely $S$. Virchow, $S$. Typhimurium and $S$. Newport. The non identified serotypes were categorised as Non 
Typable.

The integrated and non integrated broiler poultry farms and processing plants selected under study were located in vicinity of Mumbai and supplying the live and processed birds to Mumbai city. In the chicken distribution chain, a farming and processing management have a significant effect on the level of Salmonella contamination (Kim et al., 2007). However in Indian processing systems though retail processing may important role but study of newly established modern poultry processing units which cater need of urban population is essential. Therefore, it is essential to understand the epidemiology of Salmonella in chicken meat production to enhance the food safety of poultry products.

The overall isolation rate was found to be $6.7 \%$ for non integrated (12.03\%) and integrated broiler farms (1.38\%), respectively. For the comparison of these findings with results from other studies in Indian and aboard, differences in study design, number of samples and types of microbiological samples must be considered. The higher isolation rate in non integrated farming system pose serious hazard to public health as majority of the farms supply birds to Indian retails shops. Over all Salmonella occurrence in this study was lower or equal than that in Japan (14.3\%) (Limawongpranee, 1999); USA (5.2 -13.4\%) (Bailey et. al. 2001); Senegal (35.1\%) (Dione et al., 2009) and Iraq (9.2\%) (Abadi and Mayah, 2012).

In this study Litter, feaces and cloaca swabs found to be major source of cross contamination at farm. The frequency of Salmonella recovery from poultry litter, feaces and cloacal swabs was similar to that of previous studies (Ayachi et al., 2010; Kumar et al., 2014; Abunna et al., 2016).
Salmonella colonize in intestinal tract, shed in the faeces and become a source of contamination for other animals, humans and the environment (Poppe, 2000). Water, drinker and workers hand samples were positive at the non-integrated farms could be due to cross contamination with the litter and faecal material. Feed samples from both the farming system found to be negative which might be result of proper procurement of feed. Abadi and Mayah (2012) also reported negative occurrence of Salmonella spp. in feed and feeder.

A large number of environmental factors including the poultry house environment, water, old litter, farm handlers, equipment and transport vehicles have been suggested as source of Salmonella infections in broiler and layer flocks, but the relative importance of these potential sources is not clearly understood (Meerburg, 2006). Low prevalence in integrated farming system may be attributed management practices carried out by integrator where, they can support farmers with procurement of chicks and feed along with technical support on biosecurity measures; while lack of operational control in non integrated farming systems might be resulted in high prevalence. The control of dissemination of Salmonella in poultry production chain is dependent on the control of transmission sources, especially litter treatment is essential to reduce Salmonella population in litter (Frederick and Huda, 2011).

Indian poultry processing industry undergoing the changes but majority of Indian consume chicken from retail shop but processed chicken market gaining importance. Salmonella isolation rate with respect to stages of processing and environment was compared amongst the two processing units analysed under study. Salmonella Processing stage wise sampling 
showed higher isolation rate $(\mathrm{p}<0.05)$ for semi-automated unit $(19.04 \%)$ than automated unit $(4.46 \%)$. Salmonellae isolated at various stages of processing during study revealed that Salmonellae were more frequently isolated from post defeathering $(27.77 \%)$ and post evisceration stages (33.33\%). Nde et al., (2007) also reported that defeathering and evisceration has been a significant source of carcass contamination, which further leads to direct contact between contaminated and uncontaminated carcasses. The rubber fingers in defeathering machine harbour pathogens, which in turn contaminates the carcass while careless manual evisceration could contaminate the carcass during evisceration as a result of spillage of intestinal content (FAO NHO 2001 and Silva, 2009). Environmental samples showed Overall per cent occurrence of 5.35 for Salmonella spp. Samples of chopping board $(22.22 \%)$, knife $(16.66 \%)$ and evisceration worker's hand (13.33\%) revealed as major source of Salmonella spp. contamination. Surprisingly scalding water, deboning table, worker's hand (Deboning) and ice were found negative for Salmonella spp. Morris and Wells (1970) reported that processing stages results in recontamination of the carcass but noticed higher isolation rate from environmental samples to which carcasses frequently come in contact. Ishola and Taiwo (2014) reported higher Salmonella isolation rate from environmental samples due to non systematic cleaning or sanitation programs. According to our knowledge this is first time in India sampling of automated chicken processing plant was done to analyse risk of Salmonella spp. in processing environment. Chlorination was found to be effective control tool as only one sample from postchlorination stages of semi-automated process was found positive, which might be attributable to proper chlorine concentration used while washing the carcasses. Bailey et. al., (2000) reported that the use of 40 to 50 ppm chlorine in the chill tank reduces the rates of Salmonella in processing plant.

The higher incidence of Salmonella spp. in samples obtained from semi-automated processing unit at the processing stages could be due to cross contamination during processing of poultry (Kottawatta et al., 2017). The issue of Salmonella should be addressed by implementing multifaceted plans which govern all phases of production from breeder farms through transport of the chicks to farms and then live birds to slaughter (Bailey et al., 2001 and Fluckey et al., 2003).

Serotypes confirmed as Salmonella Virchow, Salmonella Newport and Salmonella Typhimurium in farms and processing environments indicates that these Salmonella serotypes circulating in all farming systems and poultry processing units in and around Mumbai. Results are depicted in Table No: 03 Isolates which were positive by PCR assay but negative by serotyping has been termed as untypable. In this study, Salmonella Virchow serovar was the most frequently found in poultry farms and processing units. In general, this is consistent with previous research carried out by Khanna, 2009. Salmonella serovar Enteritidis and Typhimurium were the main serotypes isolated from poultry (Kaushik et al., 2014). Report of S. Newport in poultry farm and processing environment is a serious issue, as CDC (2005) has raised concern over the rapid rise of Salmonella serovar Newport isolates over the last decade as important causes of human Salmonellosis. Several serotypes are consistently found at a higher incidence and the distribution of Salmonella serotypes from poultry sources varies geographically and changes over a period of time (Myint, 
2004). The high rates of serogroup $S$. Virchow in our studies, may suggest that these serogroup may be more adapted to poultry farm and processing environments under study.

It is concluded that higher risk of Salmonella spp. was observed in nonintegrated farms and semi-automated processing unit. This study provides important cross sectional epidemiological information on the Salmonella spp. contamination status in the poultry farms and slaughter units in and around Mumbai. To reduce Salmonella spp. in chicken meat production system, use of single intervention strategy for Salmonella control will not eliminate it as different farming and processing systems are operated together. Therefore, it is essential to apply multiple interventions like, sourcing of Salmonella free chicks, litter management at farm, HACCP plan at the processing stages and environmental sanitation programme to avoid cross contamination.

\section{Acknowledgements}

Author thanks the Associate Dean, Bombay Veterinary College, Parel, Mumbai 400012 for providing facility to conduct of research and author also thankful to poultry farmers and processor for permitting sample collection.

\section{Authors' Contributions}

Author RNW is the main author performed field work ananlysis of samples under the supervision of AMP. VMV, RJZ and SDM helped in literature survey, drafting and finalized the manuscript.

\section{References}

Abunna, F., M. Bedasa, T. Beyene, D. Ayana, B. Mamo, and Duguma R. 2016.
Salmonella: Isolation and antimicrobial susceptibility tests on isolates collected from poultry farms in and around Modjo, Central Oromia, and Ethiopia. J. Anim. Poultry Sci. 5(2): 21-35.

Abadi- Al and Mayah- Al 2012. Isolation and identification of Salmonella spp. from chicken and chicken environment in Basrah province. MSc thesis submitted to Department of Pathology and Poultry Diseases, College of Veterinary Medicine Basrah University, Basrah, Iraq.

Ayachi A., N. Alloui, O. Bennoune and A. Kassah-laouar 2010. Survey of Salmonella serovars in broilers and laying breeding reproducers in EasternAlgeria. J. Infect. Dev. Ctries. 4(2):103-106.

Bailey, J. S., Stern, N.J. and Cox, N.A. 2000. Commercial trial evaluation of mucosal starter culture to reduce Salmonella incidence in processed broiler carcasses. J Food Prot. 63:867-870.

Bailey, J.S, Stern, J., Fedorka-Cray, P., Craven S.E., Cox, N.A., Cosby, D.E., Ladely, S. and Musgrove, M. T. 2001. Sources and movement of Salmonella through integrated poultry operations: a multistate epidemiological investigation. J Food Prot. 64: 1690-7.

Bhuvaneswari M., S. Shanmughapriya and Natarajaseenivasan K. 2015 Prevalence of Multidrug-Resistant (MDR) Salmonella enteritidis in Poultry and Backyard Chicken from Tiruchirappalli, India. Microbiol. J. 5(2): 28-35.

CDC, 2005. Salmonella surveillance: Annual summary, 2004. Atlanta, GA.

Dione M. M., M. Ieven, B. T. Garin, T. Marcotty and S. Sgeerts 2009. Prevalence and Antimicrobial Resistance of Salmonella Isolated from Broiler Farms, Chicken Carcasses, and Street-Vended Restaurants in Casamance, Senegal. J. Food Protection. 72(11): 2423-2427.

EC, 2008. Scientific Opinion of the Panel on Biological Hazards on a request from 
the European Commission on a quantitative microbiological risk assessment on Salmonella in meat: Source attribution for human salmonellosis from meat. The EFSA Journal. 625: 1-32

FAO, 2016. Drivers, dynamics and epidemiology of antimicrobial resistance in animal production ISBN 978-92-5-109441-9.

FAONWHO, 2001. Risk Characterization of Salmonella spp in Eggs and in Broiler Chickens and Listeria monocytogenes in Ready-to-Eat Foods. Report of the Joint FAO / WHO Expert Consultation on Risk Assessment of Microbiological Hazards in Food. 30 April) 4 May 2001. FAO Headquarters, Rome, Italy: FAO

Fluckey, W.M., Sanchez, M.X., Mckee, S.R., Smith, D. and Brashears, P. E. 2003. Establishment of a microbiological profile for an air-chilling poultry operation in the united states. J Food Prot. 66:272-279.

Frederick, A. and Huda, N. 2011. Salmonellas, poultry house environments and feeds: A review. J ANIM VET ADV. 10:679685.

IS 5887 1999. Methods for detection of bacteria responsible for food poisoning Part 3: General guidance on methods for the detection of Salmonella.

Ishola, O. and Taiwo, A.G. 2014. Salmonella and Escherichia coli contamination of poultry meat from a processing plant and retail markets in Ibadan, Oyo State, Nigeria SpringerPlus 3:139-148

Jennifer, H.C. and Watkins, L.K.F. 2017. CDC Health Information for International Travel. Oxford University Press 2017. Chapter 03 Salmonellosis (Nontyphoidal).

Kaushik P, A. S. Kumari, S. K. Bharti and S. Dayal 2014 Isolation and prevalence of Salmonella from chicken meat and cattle milk collected from local markets of Patna, India, Veterinary World 7(2): 62-65.
Khanna H. R. 2009. Prevalence of Salmonella in Broiler Retail Meat Shops in New Delhi, India. A Thesis Submitted To Chiang Mai University And Freie Universität Berlin in Partial Fulfilment of the requirements for the degree of Master of Veterinary Public Health.

Kiilholma, J. 2007. Food-safety concerns in the poultry sector of developing countries In. Lesna, I., Wolfs, P., Faraji, F., Roy, L., Komdeur, J., and Sabelis, M.W. (2009) Candidate predators for biological control of the poultry red mite Dermanyssus gallinae. Exp Appl Acarol. 48(1-2), 63-80.

Kim A., Y. J. Lee, M. S. Kang, S. I. Kwag and J. K. Cho 2007. Dissemination and tracking of Salmonella spp. in integrated broiler operation. J. Vet. Sci. 8(2):155-161.

Kotaiah, T. 2016. Poultry Production in India The Current Scenario. FnBnews.com.http://www.fnbnews.co $\mathrm{m} /$ Poultry/poultry-production-in-india-the-current-scenario-38620

Kottawatta, K.S.A., Van Bergen, M.A.P., Abeynayake, P., Wagenaar, J. A., KeesVeldman, T. and Kalupahana, R. S. 2017. Campylobacter in Broiler Chicken and Broiler Meat in Sri Lanka: Influence of Semi-Automated vs. Wet Market Processing on Campylobacter Contamination of Broiler Neck Skin Samples. Foods 6: 105

Kumar, T., V. R. Rajora and N. Arora 2014. Prevalence of Salmonella in pigs and broilers in the Tarai region of Uttarakhand. Indian J. Med. Microbiol. 32:99-101.

Limawongpranee S., H. Hayashidani, A.T. Okatani, K. Ono, C. Hirota, K. Kaneko and Masuo O. 1999. Prevalence and Persistence of Salmonella in Broiler Chicken Flocks. J. Vet. Med. Sci. 61(3): 255-259.

Mead, P. S., Slutsker, L., Dietz, V., McCraig, L.F., Bresee, J.S., Shapiro, C., Griffin, P.M. and Tauxe, R. V. 1999. Food related illness and death in the United 
States. Emerg Infect Dis 5: 607-634

Meerburg, B. G., Bonde, M., Brom F.W.A., Endepols, S., Jensen, A.N. and Leirs, H. 2006. Towards sustainable management of rodents in organic animal husbandry. NJAS-WAGEN J LIFE SC, 52:195205.

Morris, K. G. and Wells G. J. 1970. Salmonella contamination in poultry processing plant. Appl Microbiol. 19. 795-9.

Myint, M.S. 2004. Epidemiology of Salmonella contamination of poultry meat products: knowledge gaps in the farm to store products. Ph.D. Dissertation. University of Maryland, Maryland, USA. pp. 86-98.

Nde, C.W., McEvoy, J.M., Sherwood, J.S. and Logue, C.M. (2007). Cross contamination of turkey carcasses by Salmonella species during defeathering. Poultry Science. 86:162- 167.

Poppe, C., 2000. Salmonella Infections in the Domestic Fowl. In: Salmonella in Domestic Animals, Wray, C. and A. Wray (Eds.). CAB International, UK., ISBN-13: 9780851999166, pp: 107-132

Rahn, K., DeGrandis, S.A., Clarke, R.C., McEwen, S.A., Galán J.E., Ginocchio, C., Curtiss, R. and Gyles, C.L. 1992. Amplification of an invA gene sequence of Salmonella typhimurium by polymerase chain reaction as a specific method of detection of Salmonella. Molecular and Cellular Probes. 6(4):271-279.

\section{How to cite this article:}

Rupesh Waghamare, Ashish Paturkar, Vilas Vaidya, Ravindra Zende, Milind Chavak and Santosh Moregaonkar. 2020. Risk of Salmonella in Various Poultry Farming and Processing Operations around Mumbai, India. Int.J.Curr.Microbiol.App.Sci. 9(08): 1024-1034. doi: https://doi.org/10.20546/ijcmas.2020.908.112
Silva, M.V. 2009. Poultry and Poultry Products - Risks for Human Health (Slaughtering and Processing). Food and Agriculture Organization of the United Nations Poultry Development Review. Available from: http://www.fao.org/ docrep/013/ al742e/al742e00.pdf. Accessed on 2503-2016

USDA, 2015. Global Agricultural Information Network- Poultry and Poultry Products Annual Report. GAIN Report No IN5124

Waghamare, R.N., A.M. Paturkar, R.J. Zende, V.M. Vaidya, N.B. Aswar and Khilari, R.S. 2017. Studies on Occurrence of Invasive Salmonella spp. In Unorganised Poultry Farm to Retail Chicken Meat shops in Mumbai City. Int. J. Curr. Microbiol. App. Sci. 6(5): 630-641

WHO/FAO, 2002. Risk assessments of Salmonella in eggs and broiler chickens: Interpretative summary. Microbiological Risk Assessment Series -1

Yang, H., Dey, S., Buchanan, R. and Biswas, D. 2014. Pests in Poultry, Poultry Product-Borne Infection and Future Precautions Practical Food Safety: Contemporary Issues and Future Directions, First Edition John Wiley and Sons, Ltd. Published 2014 by John Wiley and Sons, Ltd. pp 535- 552. 